Research Paper

\title{
Propolis Standardized Extract (EPP-AF®), an Innovative Chemically and Biologically Reproducible Pharmaceutical Compound for Treating Wounds
}

\author{
Andresa Aparecida Berretta $1,2, \bowtie$, Andresa Piacezzi Nascimento², Paula Carolina Pires Bueno ${ }^{3}$, Mirela Mara \\ de Oliveira Lima Leite Vaz², Juliana Maldonado Marchetti ${ }^{1}$
}

1. Laboratório de Tecnologia Farmacêutica, Departamento de Ciências Farmacêuticas, Faculdade de Ciências Farmacêuticas de Ribeirão Preto, Universidade de São Paulo, Av. do Café s/n, 14043-903, Ribeirão Preto, SP, Brazil.

2. Laboratório de Pesquisa, Desenvolvimento \& Inovação, Apis Flora Indl. Coml. Ltda., Rua Triunfo, 945, 14020-670, Ri-

beirão Preto, SP, Brazil.

3. Instituto de Química, Universidade Estadual Paulista, Rua Francisco Degni, s/n, CEP 14800-900, Araraquara, SP, Brazil.

\footnotetext{
$\triangle$ Corresponding author: Tel.: +55 163514 4411; Fax. +55 163514 4400; E-mail: andresaberretta@hotmail.com (A. A. Berretta)

() Ivyspring International Publisher. This is an open-access article distributed under the terms of the Creative Commons License (http://creativecommons.org/ licenses/by-nc-nd/3.0/). Reproduction is permitted for personal, noncommercial use, provided that the article is in whole, unmodified, and properly cited.
}

Received: 2011.10.14; Accepted: 2012.03.09; Published: 2012.03.21

\begin{abstract}
The aim of this study was to develop a formulation, containing the propolis standardized extract $\left(\mathrm{EPP}^{-A \mathrm{~F}^{\circledR}}\right)^{\circledR}$, which can assist in the healing of skin lesions. To achieve this objective the antimicrobial activity and chemical composition of the propolis extract was determined. The final product was subjected to in vitro and in vivo pre-clinical evaluation. The broth macrodilution method was used to determine the antimicrobial activity of the extracts and formulations against the microorganisms most commonly found in burns, Pseudomonas aeruginosa, Klebsiella pneumoniae, Escherichia coli, Staphylococcus aureus and Staphylococcus epidermidis. Wistar rats with puncture wounded skin were used to evaluate the wound healing properties of propolis. The results of chemical and biological characterization demonstrated the batch-to-batch reproducibility of the standardized extract which is an unprecedented result. The antimicrobial and wound healing activity of the pharmaceutical studied showed the best results when samples contain $3.6 \%$ propolis, suggesting that this is the most promising composition.
\end{abstract}

Key words: propolis, EPP-AF ${ }^{\circledR}$, antimicrobial activity, wound healing, pharmaceutics, reproducibility

\section{Introduction}

Thermal injury is a major cause of morbidity and impaired quality of life in many areas of the world. Each year in The United States of America, more than 1.25 million people suffer burns. It has been estimated that $75 \%$ of deaths following burn injuries are related to infection [1].

The optimal dressing for the outpatient treatment of partial-thickness thermal burns continues to challenge emergency physicians and surgeons. While the ideal dressing material should be of low cost, safe and relatively painless, it should also discourage in- fection and promote fast wound healing to minimize morbidity and optimize functional and cosmetic outcomes. Furthermore, to increase outpatient compliance, the number of dressing changes should be minimized and be easily performed at home with the slightest amount of discomfort [2].

Nalbandian et al. (1987) developed a poloxamer 407 gel for dermatological and burn treatment, because of its water solubility, adherence and easy application and removal from the burn sites [3]. Poloxamer 407 is an inert, atoxic substance that is able 
to generate thermoreversible colloidal solutions in the presence of water, as a consequence of its aggregation into micelles, which occurs with increasing temperature, minimizing the free energy of the solution. At low temperatures, the polymer exists as a monomer in solution. Upon warming, a balance is established between monomers and micelles, and aggregates are formed [4].

In addition to the need for more convenient wound dressing and pharmaceuticals, it is also important to discover therapeutic agents that are more effective against microbial infections frequently related with burns.

Propolis is a resinous balsamic material, with a complex chemical composition, which is collected by bees from sprouts, exudates of trees and other parts of the plants. It is modified in the beehive by addition of salivary secretions and wax [5]. It is used by bees for protection, repair of holes and damage to the hive, and for the construction of aseptic places for the queen to lay her eggs [6]. More than 150 components, including polyphenols, terpenoids, steroids, sugars and amino acids, have been identified in raw propolis. Its chemical composition is influenced by botanical and geographical factors, as well as the collection season. In general, propolis consists of $50 \%$ resin and vegetable balsam, $30 \%$ wax, $10 \%$ essential and aromatic oils, $5 \%$ pollen, and $5 \%$ other substances including organic debris [7].

Several studies have been published on the many different existing propolis extracts, both with regard to their biological activities [8-10] and safety [7]. However, it is impossible to compile all data for the generation of a pharmaceutical product. The origin, composition and extractive processes alter the extract obtained and subsequently biological behavior of the product. Therefore, the propolis standardized extract $\left(\mathrm{EPP}-\mathrm{AF}^{\circledR}\right)$ used in this study offers some advantages over the others, since some of its biological activities [5; 11-14] and safety [11] have been studied previously in other models, which allowed greater security for the realization of this proposal.

The EPP-AF ${ }^{\circledR}$ showed anti-inflammatory [11], anti-ulcer [12], antimicrobial [13], antioxidant [5] and antifungal activities [14]. Furthermore, its safety has been demonstrated [11] and the absence of cytotoxicity and mutagenic potential evaluated [15-16]. With the data available, all obtained from the same extract with the same composition of the propolis raw material, and the same chemical extracting process, it is possible to get a drug. Aiming to achieve this goal, this study proposed to evaluate three batches of $\mathrm{EPP}-\mathrm{AF}^{\circledR}$ assessing its chemical composition and bio- logical properties in order to determine the reproducibility of the product batch-to-batch.

For wound dressing application, several polymeric materials have been investigated with successful outcomes, but an ideal skin substitute with structural and functional properties similar to those of human skin requires further investigated [17].

Considering this information, a pharmaceutical compound was developed, containing the propolis extract, designed to be used for treating wounds, as a product suited for this application is still required. In addition to the chemical characterization of the propolis extracts and evaluation of its reproducibility, the final product was subjected to in vitro (antimicrobial activity) and in vivo (wound healing) pre-clinical evaluation.

\section{Materials and Methods}

\section{Chemicals}

Three batches of green propolis standardized extracts (EPP-AF $\left.{ }^{\circledR}\right)$ A $(010 / 08), B(1440110)$ and C (1400410), were kindly provided by Apis Flora Co. (Ribeirão Preto, São Paulo, Brazil) (patent PI 0405483-0, Revista de Propriedade Industrial No. 1778 of $01 / 02 / 2005$ ). Propolis glycolic extract (PGE) was obtained from EPP-AF ${ }^{\circledR}$ after evaporation of the ethanol portion and the addition of propyleneglycol to achieve $30 \% \mathrm{w} / \mathrm{v}$ of dry matter. For quantitative analysis caffeic, $p$-coumaric and trans-cinnamic acids (Sigma-Aldrich , São Paulo, Brazil); artepillin C (Wako Pure Chemical Industries Co., Osaka, Japan); gallic acid (Labsynth, Diadema, Brazil); isosakuranetin (ChromaDex, Irvine, Canada) and aromadendrin-4'-O-methyl ether (previously isolated and identified as described by Sousa et al. [18] and kindly donated by the authors) were used. Methanol HPLC-grade was obtained from J.T. Baker and water was treated in a Milli-Q water purification system. All other chemicals were of reagent grade and were used without further purification. Mueller Hinton agar and Mueller Hinton broth (Difco, Detroid, MI, USA), were used for the microbial assays.

\section{Chemical Analysis of propolis extracts by HPLC}

The propolis extracts were analyzed by HPLC using a Shimadzu apparatus equipped with a CBM-20A controller, a LC-20AT quaternary pump, a SPD-M 20A diode-array detector, and Shimadzu LC solution software, version 1.21 SP1. A Shimadzu Shim-Pack CLC-ODS column (4.6 mm x $250 \mathrm{~mm}$, particle diameter of $5 \mu \mathrm{m}$, pore diameter of $100 \AA$ ) was used. The mobile phase consisted of methanol (B), and 
of a solution of water-formic acid $(0.1 \% \mathrm{v} / \mathrm{v}), \mathrm{pH} 2.7$ (A). The method consisted of a linear gradient of $20-95 \%$ of B over a period of 77 minutes at a flow rate of $0.8 \mathrm{ml} / \mathrm{min}$. Detection was set at $275 \mathrm{~nm}$.

Propolis extracts were diluted with $5 \mathrm{ml}$ of methanol (HPLC grade) in $10 \mathrm{ml}$ volumetric flasks, subjected to sonication for 10 minutes and filled to volume with Milli-Q water. The samples were filtered through a $0.45 \mu \mathrm{m}$ filter before analysis.

\section{Preparation of thermoreversible formulations}

The raw material used for the formulations included the polymer poloxamer 407, a co-surfactant ethoxylated castor oil (BASF, São Paulo, Brazil) sodium sorbate (Labsynth, Diadema, Brazil) and water. The gels (patent PI 0806114-9) were prepared on a weight basis using the cold method according to Schmolka [19]. Appropriate amounts of PGE and co-surfactant were mixed to yield 1.2, 2.4 and 3.6\% $(\mathrm{w} / \mathrm{w})$ dry propolis extract (samples 1,2 and 3, respectively), in accord with previous publication by our group [15]. Two control samples were prepared: one consisting of the polymer dispersion in water (control 1) and the other of polymer and co-surfactant in water (control 2) at concentrations same to those used for the propolis gels.

\section{Antimicrobial activity}

Pseudomonas aeruginosa ATCC 27853, Klebsiella pneumoniae ATCC 10031, Escherichia coli ATCC 25922, Staphylococcus aureus ATCC 25923, Staphylococcus aureus ATCC 43300, and Staphylococcus epidermidis ATCC 14990 were acquired from the American Type Culture Collection (ATCC).

The three batches of $\operatorname{EPP}^{-A F^{\circledR}}(\mathrm{A}, \mathrm{B}$ and $\mathrm{C})$ and the formulations (samples 1, 2 and 3) containing the PGE extracts respectively, and the controls (1 and 2) were evaluated.

The antimicrobial activity of the EPP-AF ${ }^{\circledR}$ and formulations were determined by the broth macrodilution method [20] with some adaptations for natural products. Sterile test tubes and Mueller Hinton broth were used for the tests.

As a result of the turbidity that occurred in test broth when EPP-AF ${ }^{\circledR}$ was diluted, it was not possible to determine the minimum inhibitory concentration (MIC). Therefore, the antimicrobial activity of the $\mathrm{EPP}^{-\mathrm{AF}^{\circledR}}{ }$ was assessed by means of the minimum bactericidal concentration (MBC), which was determined by subculturing $20 \mu \mathrm{l}$ aliquots from each tube in the broth dilution series onto Mueller Hinton agar plates. The plates were incubated at $35^{\circ} \mathrm{C}$ for $24 \mathrm{~h}$. The $\mathrm{MBC}$ was defined as the lowest concentration of the sample required to kill the microorganism being tested. In the case of the gels, this turbidity does not occur and therefore the antimicrobial activity was determined by MIC [20].

\section{In vivo models for wound healing activity}

Thirty male Wistar rats (Rattus norvegicus, Berkenout, 1769) with an initial body weight of $45 \mathrm{~g}$, obtained from the Central Animal House, Faculty of Medicine of Ribeirão Preto, University of São Paulo, Brazil, were used. The protocol was approved by the Ethics Committee for Animal Care of the University of Franca (process 121/05).

A lesion was created with a punch on the back of animals previously anesthetized by intraperitoneal administration of ketamine, midazolam and acepram [21]. After surgery the animals received no additional treatment (antibiotics or anti-inflammatory drugs), only food and water ad libitum. The cages were cleaned daily and kept in air conditioned environment. The concentrations of the propolis extract added to the formulations used in the present study were established based on ethnopharmacological information [22]. The animals were treated with gels in the presence and absence of propolis $\left(\mathrm{EPP}^{-\mathrm{AF}^{\circledR}}\right)(\mathrm{n}=$ 3). The animals were fed and weighed daily.

The healing process was evaluated by two experimental protocols. At first, there was a single application of the product under test, and the animals were sacrificed three days after the completion of the surgical incision $(n=3)$. In the second protocol, the products were applied twice a day (each 12 hours), and the animals were sacrificed three days after incision $(\mathrm{n}=3)$.

The animals were sacrificed with lethal doses of anesthetic and the tissue containing the lesions were fixed in $4 \%$ formaldehyde in Sorensen phosphate buffer $0.1 \mathrm{M}, \mathrm{pH}$ 7.3. The samples were placed in paraffin and sliced by a microtome in slices of $6 \mu \mathrm{m}$. The sections were stained with Masson trichrome staining and analyzed by optical microscopy [23].

The micro measurements of the affected area were performed using three sections per rat with 25 $\mu \mathrm{m}$ of distance between each section totaling $93 \mu \mathrm{m}$ per treatment. The morphometry of the lesion, in all groups and treatments, was evaluated using an image analyzer KS300 - Zeiss (Axion Vision) with a 40x magnification. The results are presented as mean tissue filler by micrometers.

\section{Statistical analysis}

The statistical analysis was performed by the Pearson correlation coefficient (r) obtained by the correlation of the markers in three batches studied $(n=4)$. The $r^{2}$ value was expressed as percentage of 
correlation. The Pearson's coefficients obtained were subjected to analysis of variance (ANOVA) with Bonferroni multiple comparison post-test (level of significance of $5 \%$ ). The data of the antimicrobial activity were submitted to the nonparametric Kruskal-Wallis test (significance level of 1\%). Statistical analysis of data was performed using the software Graph Pad Prism 4.

\section{Results}

\section{Chemical characterization of EPP-AF ${ }^{\circledR}$}

Correlation analyses indicated that there was a significant relationship between batch $\mathrm{A}$ and $\mathrm{B}$ (99.61\%), B and C (99.72\%), and between A and C $(99.71 \%)$, demonstrating the chemical reproducibility of the three batches ( $p>0.05)$. The chemical characterization results demonstrate that the three batches studied were similar, since the presence and quantification of the six standards studied (caffeic, $p$-coumaric and trans-cinnamic acids, aromadendrin, isosakuranetin and artepillin C) were similar batch-to-batch ( $\mathrm{p}>0.05)$.

Table 1 and Figure 1 show the quantitative analysis of the three batches of EPP-AF ${ }^{\circledR}$ and their chromatograms, respectively.

It is important to point out that the chemical markers quantified represent three important groups of metabolites commonly found in propolis products: the flavonoids, the prenilated phenolic compounds and phenolic acids. The unidentified peaks in the chromatograms are undergoing further investigation. Nonetheless, the chemical markers used in this study are distributed along the chromatogram allowing more confidence for chemical profile analysis.

Table I Chemical characterization of the standardized propolis extracts $\left(E P P-A F^{\circledR}\right)$ used in this study $(n=4)(m g / g)$.

\begin{tabular}{llll}
\hline \multirow{2}{*}{ Compounds } & \multicolumn{3}{l}{ Standardized Propolis Extract } \\
\cline { 2 - 4 } & $\mathrm{A}^{\mathrm{a}}$ & $\mathrm{B}^{\mathrm{b}}$ & $\mathrm{C}^{\mathrm{c}}$ \\
\hline caffeic acid & $0.299 \pm 0.024$ & $0.336 \pm 0.027$ & $0.288 \pm 0.009$ \\
$p$ - coumaric acid & $1.561 \pm 0.090$ & $1.524 \pm 0.108$ & $1.486 \pm 0.052$ \\
trans-cinnamic acid & $0.091 \pm 0.055$ & $0.167 \pm 0.001$ & $0.153 \pm 0.009$ \\
aromadendrin & $1.020 \pm 0.168$ & $0.993 \pm 0.075$ & $1.125 \pm 0.022$ \\
isosakuranetin & $2.261 \pm 0.135$ & $2.256 \pm 0.144$ & $2.265 \pm 0.084$ \\
artepilin C & $7.553 \pm 1.497$ & $8.533 \pm 0.522$ & $6.962 \pm 0.261$ \\
\hline
\end{tabular}

a Batch $010 / 08$ of EPP-AF ${ }^{\circledR}$.

b Batch 1440110 of EPP-AF®.

c Batch 1400410 of EPP-AF ${ }^{\circledR}$.
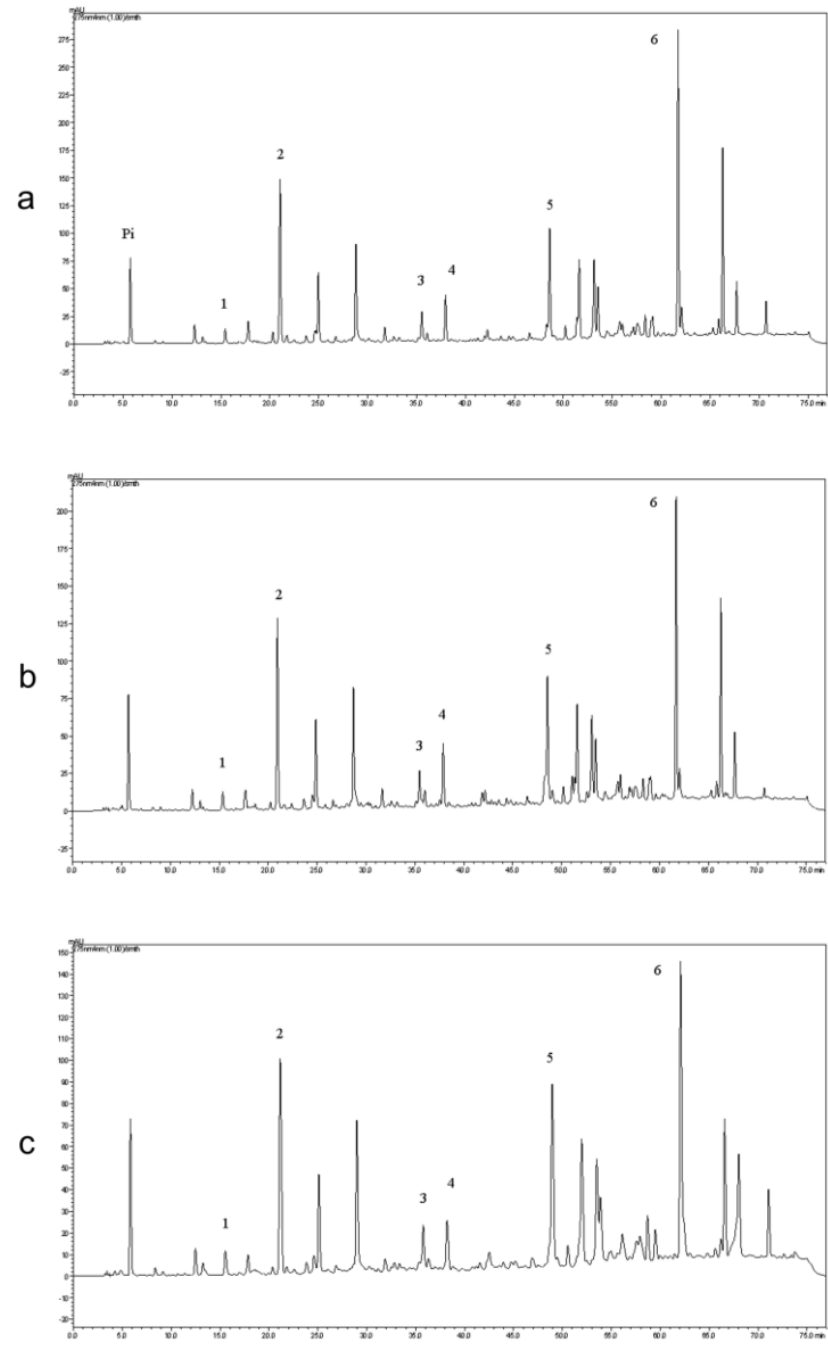

Figure I: Chromatographic profile of (a) Propolis Standardized Extract $\left(\right.$ EPP-AF $\left.{ }^{\circledR}\right)$ Batch I440II0 ; (b) Batch I4004I0 and (c) Batch 010/08. Chromatographic profile includes the compounds: I. Caffeic acid (around 15 min.); 2. p-coumaric acid (around 20 min.); 3. trans-cinnamic acid (around $36 \mathrm{~min}$.), 4. aromadendrin (38 min.) 5. isosakuretin (around $48 \mathrm{~min}$.) and 6.Artepillin $C$ (around $61 \mathrm{~min}$.). The chromatograms were plotted at $275 \mathrm{~nm}$, using the RP-HPLC, CI 8 (Shim-pack, CLC-ODS (M), $25 \mathrm{~cm} \times 4.6$ ) column and gradient elution with methanol and acidic water (formic acid $\mathrm{pH}=2.7)$.

\section{Antimicrobial activity of EPP-AF ${ }^{\circledR}$ Extracts - Minimal Bactericidal Concentration (MBC)}

The three batches of EPP-AF ${ }^{\circledR}$ studied, showed in vitro antimicrobial activity against all the tested microorganisms (Table 2). The statistical analysis demonstrated no significant difference $(p>0.05)$ among the three batches (A, B and C). Gram positive bacteria (Staphylococci) were more sensitive to $\mathrm{EPP}^{\mathrm{A}} \mathrm{AF}^{\circledR}$ than Gram negative bacteria (P. aeruginosa, K. pneumoniae and E. coli) $(\mathrm{p}<0.01)$. 
Table 2: Minimum bactericidal concentration (MBC) of the three batches of standardized propolis extract (EPP-AF ${ }^{\circledR}$ $A, B$ and C) $(n=3)$.

\begin{tabular}{llll}
\hline Microorganism & \multicolumn{3}{c}{$\begin{array}{l}\mathrm{MBC} \\
(\mathrm{mg} / \mathrm{mL})\end{array}$} \\
\cline { 2 - 4 } & $\begin{array}{l}\mathrm{A}^{\mathrm{a}} \\
\text { Mean } \\
(\mathrm{SD})\end{array}$ & $\begin{array}{l}\mathrm{B}^{\mathrm{b}} \\
\text { Mean (SD) }\end{array}$ & $\begin{array}{l}\mathrm{C}^{\mathrm{c}} \\
\text { Mean } \\
(\mathrm{SD})\end{array}$ \\
\hline $\begin{array}{l}\text { Pseudomonas aeruginosa } \\
\text { ATCC 27853 }\end{array}$ & $\begin{array}{l}14.05 \\
(0.00)\end{array}$ & $13.93(0.00)$ & $\begin{array}{l}14.00 \\
(0.00)\end{array}$ \\
$\begin{array}{l}\text { Klebsiella pneumoniae ATCC } \\
10031\end{array}$ & $\begin{array}{l}14.05 \\
\text { 10.00) }\end{array}$ & $13.93(0.00)$ & $\begin{array}{l}14.00 \\
(0.00)\end{array}$ \\
Escherichia coli ATCC 25922 & $\begin{array}{l}14.05 \\
(0.00)\end{array}$ & $13.93(0.00)$ & $\begin{array}{l}14.00 \\
(0.00)\end{array}$ \\
Staphylococcus aureus ATCC & $7.02(0.00)$ & $6.96(0.00)$ & $7.00(0.00)$ \\
25923 & & & \\
Staphylococcus aureus ATCC & $3.51(0.00)$ & $3.48(0.00)$ & $3.50(0.00)$ \\
43300 & & & $7.00(0.00)$ \\
Staphylococcus epidermidis & $7.02(0.00)$ & $6.96(0.00)$ & \\
ATCC 14990 & & & \\
\hline
\end{tabular}

a Batch 10/08 of EPP-AF ${ }^{\circledR}(11.24 \% \mathrm{w} / \mathrm{v}$ dry propolis extract).

b Batch 1440110 of EPP-AF ${ }^{\circledR}$ (11.15\% w/v dry propolis extract).

c Batch 1400410 of EPP-AF ${ }^{\circledR}(11.20 \% \mathrm{w} / \mathrm{v}$ dry propolis extract).

\section{Wound Healing activity}

The histological slices obtained from animals treated with saline (control), gel without propolis and gel containing $1.2 \%, 2.4 \%$ and $3.6 \% \mathrm{w} / \mathrm{v}$ (dry matter) of propolis during the three days treatment. Figure $2 \mathrm{~A}$ corresponds to the injured tissue treated with saline, while Figures $2 \mathrm{~B}$ and $\mathrm{C}$ depict the treatment with gel in the absence of propolis. The histological section shows the onset of the healing process, where there is an intense presence of immune cells, especially the cream leukocytes (arrows).

Treatment with the sample 1, which contained $1.2 \%$ propolis shows the healing process is more developed. In addition there is the presence of a large number of newly formed vessels, fibroblasts and the presence of plasma cells (Figure 3A and B). With this treatment it can be seen that epithelial cells are organizing clots just below the initial lesion (arrow Figure $3 \mathrm{~A}$ ) and the presence of collagen fibers was noted (Figure $3 \mathrm{~B}$ ).

Treatment with the sample 2, containing 2.4\% propolis demonstrated earlier healing than that observed with sample 1 . Figure $4 \mathrm{~A}$ shows the closure of the injury, where there is a region with epithelial cells and the presence of organized collagen fibers (arrow). Subcutaneously (Fig. 4B) it is clear the tissue contains fibroblasts and collagen, and also a large number of mitotic cells (arrows), showing that propolis stimulates cell proliferation and tissue repair.
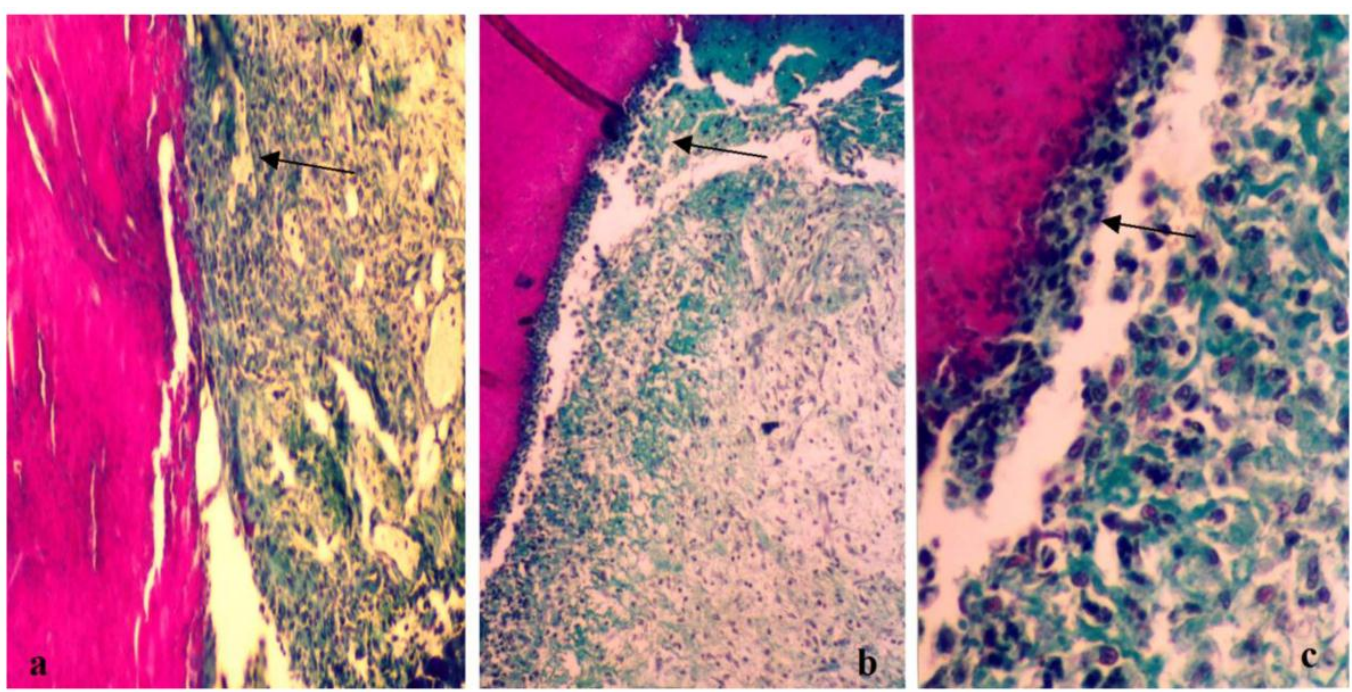

Figure 2: Photograph showing the healing process of the control group $(A)$ and the group treated with gel in the absence of propolis (B and C) after 3 days of treatment. Slices of $6 \mu \mathrm{m}$ were obtained and stained with Masson's trichromic. a) Lesions treated with saline (control). Start of the healing process (100x magnification); b) Lesions treated with gel without propolis. Start of the healing process (I00x magnification); c) Lesions treated with gel without propolis. Cream leukocitary cells (arrow) observed just below the initial clot $(*)(400 X$ magnification). 

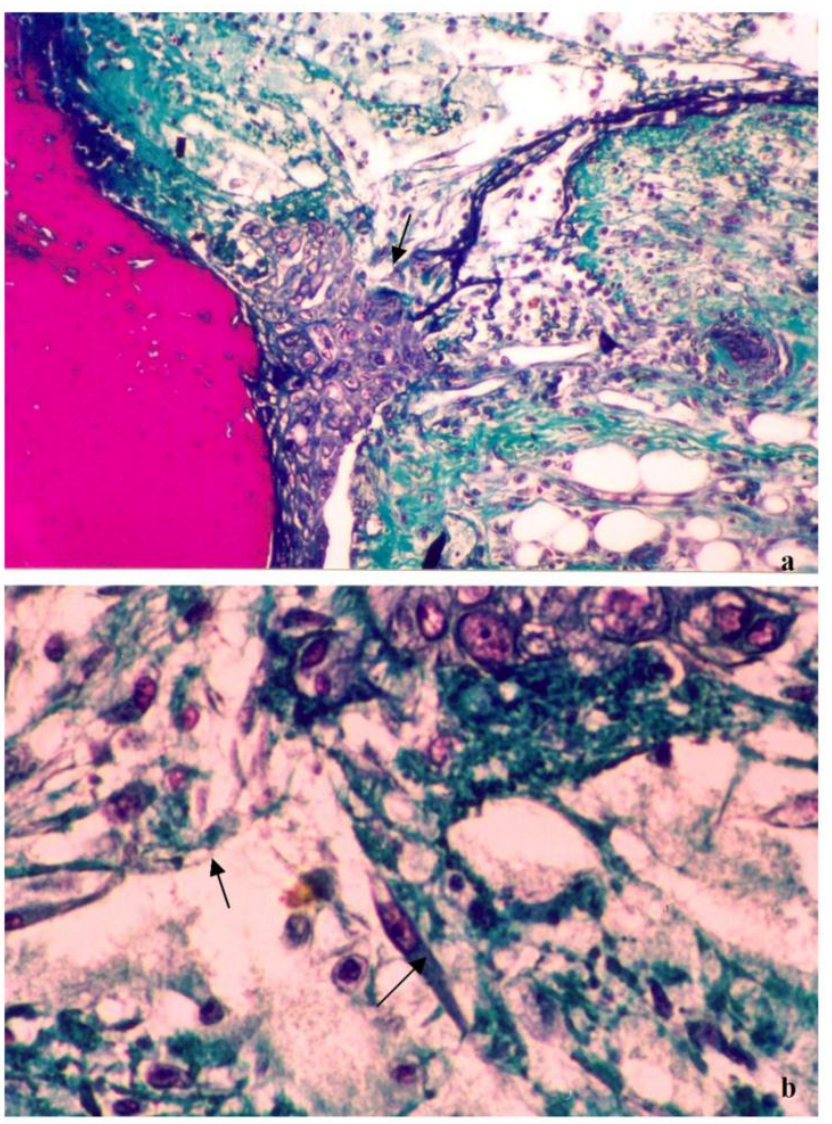

Figure 3: Photograph showing the healing process after three days of treatment with the gel containing 1.2\% of dry extract of propolis. a) Lesions treated with gel containing standardized extract of propolis (I.2\%) in the subcutaneous tissue. The reorganization of epithelial cells (c) and increased collagen fibers were observed just below the initial clot $(*)$. Slices of $6 \mu \mathrm{m}$ were obtained and stained with Masson's trichromic (100x magnification); b) lesions treated with gel containing standardized extract of propolis (1.2\%). There are a large number of fibroblasts synthesizing collagen (arrow). Slices of $6 \mu \mathrm{m}$ were obtained and stained with Masson's trichromic (400X magnification).

Figure $4 \mathrm{C}$ corresponds to the treatment performed with sample 3, which contained $3.6 \%$ propolis, where it is possible to see the tissue is completely reconstituted, where all the corneal layer is formed, consisting of properly organized epithelial tissue (1). The subcutaneous region presents a dense and well-structured tissue with the presence of collagen, however without the required extracellular matrix.

Histological findings have shown that with just one application of the gels containing $\mathrm{EPP}-\mathrm{AF}^{\circledR}$, an organized tissue was formed and maintained with physiological functions (Figure 4). It could also be observed that the healing effect was almost the same between the concentrations of $2.4 \%$ and $3.6 \%$. The repetition of the applications was more effective when we compare the morphometric analysis of the healing area. The analysis noted that the area of newly formed tissue was significantly higher for the individual applications of samples 2 and 3 when compared to sample 1 application. No significant difference in morphometric area was observed between samples 2 and $3(\mathrm{p}>0.05)$.
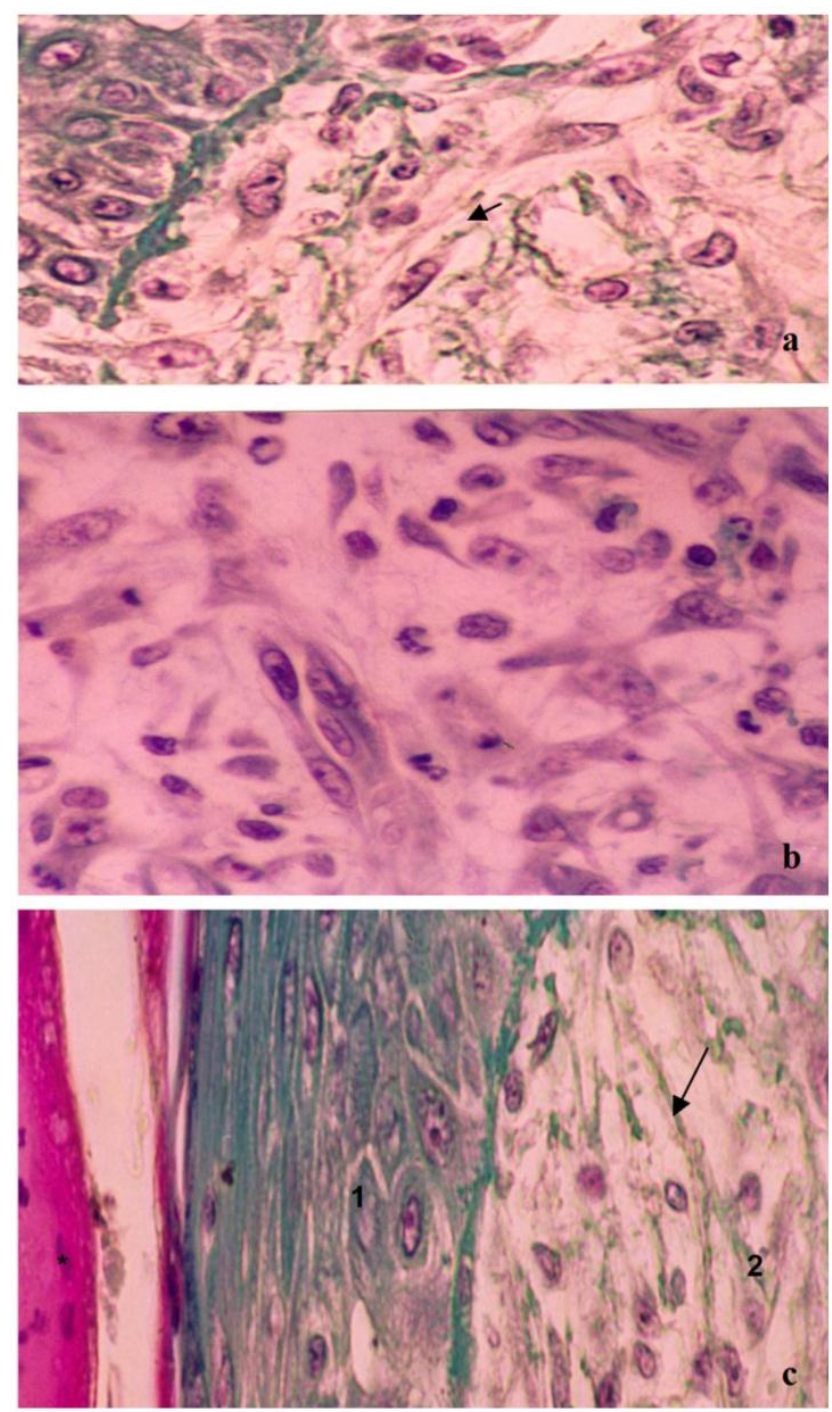

Figure 4: Photograph showing the healing process after three days of treatment with the gels containing either $2.4 \%$ or $3.6 \%$ propolis. Slices of $6 \mu \mathrm{m}$ were obtained and stained with Masson's trichromic. a) Lesions treated with the $2.4 \%$ propolis gel. Closing of the lesion in the epithelial layer (I) and subcutaneously (2) there is a large number of fibroblasts synthesizing collagen (arrow) ( $100 x$ magnification); b) Lesion treated with the $2.4 \%$ propolis gel. Subcutaneously (2) there is an increase of collagen fibers and a large number of cells undergoing mitosis (arrow) (400X magnification); c) Lesions treated with the $3.6 \%$ propolis gel. Wound area completely rebuilt, the epithelium $(\mathrm{I})$ is already presented in several layers forming the corneal region. Subcutaneously (2) thicker collagen fibers (arrow) were observed (400X magnification). 
Through the data presented with increasing concentration of propolis, a greater number of mitotic cells were observed, suggesting a role for this product as a stimulator of fibroblast growth. The present results showed the healing activity of the gel containing EPP-AF ${ }^{\circledR}$, especially with samples 2 and 3, after three days of treatment, while in the control group, seven days was required to obtain tissue repaired.

\section{Antimicrobial activity of Thermoreversible Gels - Minimal Inhibitory Concentration (MIC)}

Samples 1 and 2 were not effective against the tested microorganisms (Table 3). However, sample 3 showed in vitro antimicrobial activity against all $\mathrm{mi}-$ croorganisms (Table 3). Sample 3 was statistically more efficacious in inhibiting growth of the microorganisms than samples 1 and $2(p<0.001)$. No significant difference was found between samples 1 and 2 $(p>0.05)$. Control sample (without EPP-AF ${ }^{\circledR}$ ) was not effective against the tested microorganisms.

\section{Discussion}

Sforcin and Bankova (2011) [24] presented the difficulties in developing a drug based on propolis, although numerous scientific data-sets have shown the biological activities of propolis and its safety. The origin of propolis, its mode of production and chemical composition can be different, hindering obtaining a safe and effective medicine.

Batch variability is a common drawback in the manufacture of plant extracts. Medicinal use of natural compounds must rely on appropriate quality, safety, and efficacy requisites. In this regard, batch-to-batch reproducibility is essential to ensure consistent quality. In the present study, compounds such as phenolics, cinnamic acid derivatives, flavonoids (aromadendrin and isosakuranetin), a representative of prenylated $p$-coumaric acids, artepillin C, an important and internationally recognized biomarker for propolis of the Brazilian type [15;18].

The results presented in this study, demonstrated for the first time in the literature the chemical reproducibility of three independent batches of propolis extract compared with six standards. Almeida et al. (2010) studied the chemical and functional reproducibility of the extracts from Castanea sativa, by comparing the fingerprint of the three extracts with respect of the phenolic composition. Although the chromatographic profile showed several peaks, like in this study, only the hyperoside, isoquercitrin, rutin and ellagic acid were identified [25]. The identification and analysis of some applicable chemical markers (not all peaks found in the chromatogram) is common in phytotherapeutic studies because it is quite difficult to identify all compounds in the sample. Nonetheless, the batch-to-batch reproducibility can be demonstrated considering a group of standards. Then, in the presented investigation, although all the peaks presented in the chromatograms were not identified (studies running), the chemical reproducibility obtained is a remarkable fact considering the area of research in question. Working in the field of technological innovation, these findings suggest that propolis $\mathrm{EPP}^{-\mathrm{AF}^{\circledR}}{ }^{\circledR}$ an be used as a drug.

Table 3 Minimum inhibitory concentration (MIC) of the formulations (samples I, 2 and 3 ) containing the batches A, B and $C$ of standardized propolis extract $\left(\operatorname{EPP}_{-}-\mathrm{AF}^{\circledR}\right)(\mathrm{n}=3)$.

\begin{tabular}{|c|c|c|c|c|c|c|c|c|c|}
\hline \multirow[t]{3}{*}{ Microorganism } & \multicolumn{9}{|c|}{$\mathrm{MIC}(\mathrm{mg} / \mathrm{mL})$} \\
\hline & \multicolumn{3}{|l|}{ Sample $1^{\mathrm{a}}$} & \multicolumn{3}{|l|}{ Sample $2^{\mathrm{b}}$} & \multicolumn{3}{|l|}{ Sample 3c } \\
\hline & $\begin{array}{l}\mathrm{A}^{\mathrm{d}} \\
\text { Mean (SD) }\end{array}$ & $\begin{array}{l}\text { Be } \\
\text { Mean (SD) }\end{array}$ & $\begin{array}{l}\mathrm{C}^{\mathrm{f}} \\
\text { Mean (SD) }\end{array}$ & $\begin{array}{l}\text { A } \\
\text { Mean (SD) }\end{array}$ & $\begin{array}{l}\text { B } \\
\text { Mean (SD) }\end{array}$ & $\begin{array}{l}\text { C } \\
\text { Mean (SD) }\end{array}$ & $\begin{array}{l}\text { A } \\
\text { Mean (SD) }\end{array}$ & $\begin{array}{l}\text { B } \\
\text { Mean (SD) }\end{array}$ & $\begin{array}{l}\text { C } \\
\text { Mean (SD) }\end{array}$ \\
\hline P. aeruginosa ATCC 27853 & $\begin{array}{l}>6 \\
(0.00)\end{array}$ & $\begin{array}{l}>6 \\
(0.00)\end{array}$ & $\begin{array}{l}>6 \\
(0.00)\end{array}$ & $\begin{array}{l}>12 \\
(0.00)\end{array}$ & $\begin{array}{l}>12 \\
(0.00)\end{array}$ & $\begin{array}{l}>12 \\
(0.00)\end{array}$ & $\begin{array}{l}18 \\
(0.00)\end{array}$ & $\begin{array}{l}18 \\
(0.00)\end{array}$ & $\begin{array}{l}18 \\
(0.00)\end{array}$ \\
\hline $\begin{array}{l}\text { K. pneumoniae } \\
\text { ATCC } 10031\end{array}$ & $\begin{array}{l}>6 \\
(0.00)\end{array}$ & $\begin{array}{l}>6 \\
(0.00)\end{array}$ & $\begin{array}{l}>6 \\
(0.00)\end{array}$ & $\begin{array}{l}>12 \\
(0.00)\end{array}$ & $\begin{array}{l}>12 \\
(0.00)\end{array}$ & $\begin{array}{l}>12 \\
(0.00)\end{array}$ & $\begin{array}{l}18 \\
(0.00)\end{array}$ & $\begin{array}{l}18 \\
(0.00)\end{array}$ & $\begin{array}{l}18 \\
(0.00)\end{array}$ \\
\hline $\begin{array}{l}\text { E. coli } \\
\text { ATCC } 25922\end{array}$ & $\begin{array}{l}>6 \\
(0.00)\end{array}$ & $\begin{array}{l}>6 \\
(0.00)\end{array}$ & $\begin{array}{l}>6 \\
(0.00)\end{array}$ & $\begin{array}{l}>12 \\
(0.00)\end{array}$ & $\begin{array}{l}>12 \\
(0.00)\end{array}$ & $\begin{array}{l}>12 \\
(0.00)\end{array}$ & $\begin{array}{l}18 \\
(0.00)\end{array}$ & $\begin{array}{l}18 \\
(0.00)\end{array}$ & $\begin{array}{l}18 \\
(0.00)\end{array}$ \\
\hline $\begin{array}{l}\text { S. aureus } \\
\text { ATCC } 25923\end{array}$ & $\begin{array}{l}>6 \\
(0.00)\end{array}$ & $\begin{array}{l}>6 \\
(0.00)\end{array}$ & $\begin{array}{l}>6 \\
(0.00)\end{array}$ & $\begin{array}{l}>12 \\
(0.00)\end{array}$ & $\begin{array}{l}>12 \\
(0.00)\end{array}$ & $\begin{array}{l}>12 \\
(0.00)\end{array}$ & $\begin{array}{l}9 \\
(0.00)\end{array}$ & $\begin{array}{l}9 \\
(0.00)\end{array}$ & $\begin{array}{l}9 \\
(0.00)\end{array}$ \\
\hline $\begin{array}{l}\text { S. aureus } \\
\text { ATCC } 43300\end{array}$ & $\begin{array}{l}>6 \\
(0.00)\end{array}$ & $\begin{array}{l}>6 \\
(0.00)\end{array}$ & $\begin{array}{l}>6 \\
(0.00)\end{array}$ & $\begin{array}{l}>12 \\
(0.00)\end{array}$ & $\begin{array}{l}>12 \\
(0.00)\end{array}$ & $\begin{array}{l}>12 \\
(0.00)\end{array}$ & $\begin{array}{l}9 \\
(0.00)\end{array}$ & $\begin{array}{l}9 \\
(0.00)\end{array}$ & $\begin{array}{l}9 \\
(0.00)\end{array}$ \\
\hline S. epidermidis ATCC 14990 & $\begin{array}{l}>6 \\
(0.00)\end{array}$ & $\begin{array}{l}>6 \\
(0.00)\end{array}$ & $\begin{array}{l}>6 \\
(0.00)\end{array}$ & $\begin{array}{l}>12 \\
(0.00)\end{array}$ & $\begin{array}{l}>12 \\
(0.00)\end{array}$ & $\begin{array}{l}>12 \\
(0.00)\end{array}$ & $\begin{array}{l}9 \\
(0.00)\end{array}$ & $\begin{array}{l}9 \\
(0.00)\end{array}$ & $\begin{array}{l}9 \\
(0.00)\end{array}$ \\
\hline
\end{tabular}

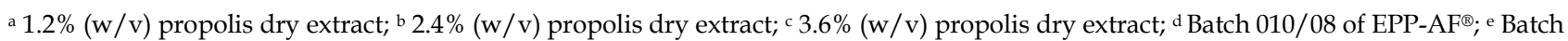
1440110 of EPP-AF®; ${ }^{\mathrm{f}}$ Batch 1400410 of EPP-AF ${ }^{\circledR}$. 
The microorganisms studied $P$. aeruginosa, $K$. pneumoniae, E. coli, S. aureus and S. epidermidis. P. aeruginosa are the most frequently isolated from injuries and burn wound, followed by K. pneumoniae, E. coli, S. aureus and the coagulase-negative staphylococci [1]. $S$. aureus ATCC 43300 is a methicillin-resistant $S$. aureus (MRSA). These strains are resistant to all penicillins, cephalosporins and carbapenems. However, EPP-AF ${ }^{\circledR}$ showed antimicrobial activity against these microorganisms, demonstrating the functional reproducibility of EPP-AF ${ }^{\circledR}$ similar to that obtained by Almeida et al. (2010) in the case of antioxidant activity of Castanea sativa [25]. Furthermore, EPP-AF ${ }^{\circledR}$ killed S. aureus ATCC 43300 with a range of concentration $3.48-3.51$ $\mathrm{mg} / \mathrm{ml}$, while it killed other staphylococci with higher concentrations (6.96 - $7.02 \mathrm{mg} / \mathrm{ml})$ (Table 2). Gram-negative bacteria were killed with higher concentrations of EPP-AF®. Erkmen and Özcan (2008) [26] reported that Gram-positive bacteria were more susceptible to Turkish propolis extracts than Gram-negative bacteria. Similar result occurred with the propolis evaluated in this work.

Until the present moment, the mechanisms of action related to the biological activities of propolis remains unknown. Menna-Barreto et al. (2009) showed that susceptibility of $T$. cruzi treated with propolis was affected by the reservosomes, suggesting a failure in the lipid metabolism, affecting membrane fluidity and leading to cell lysis [27]. Takaisi \& Schilcher (1994) suggested that the antimicrobial activity of propolis is due to a combined action of pinocembrine, galangin and caffeic acid phenethyl ester (CAPE), whose action is based on the inhibition of bacterial RNA polymerase [28]. However, the flavonoid compounds presented in this works are characteristic of propolis originating from Poplar buttons (Populus sp.) and therefore referring of European propolis, hence such data cannot simply be extrapolated to the Brazilian propolis [24]. Furthermore, the research of CAPE in the EPP-AF® demonstrated that this compound is not present in its composition (data not shown).

Recently, studies done by our group using Saccharomyces cerevisiae models demonstrated that short exposure to the propolis standardized extract (EPP-AF®) was able to induce cell death by apoptosis, while contact for longer periods caused necrosis [14]. The results of De Castro et al. (2011) also indicate that cytochrome $c$ and endonuclease G (Nuc 1p) are involved in cell death induced by propolis and that the metacaspase YCA1 gene is one of the important mediators in this induction. Systems biology revealed enrichment for genes involved in the mitochondrial electron transport chain, vacuolar acidification, nega- tive regulation of transcription from the RNA polymerase II promoter, regulation of macroautophagy associated with protein targeting to vacuoles, and cellular responses to starvation. Validation studies indicated that propolis sensitivity is dependent on the mitochondrial function and that vacuolar acidification and autophagy are important for cell death caused by propolis [14]. The same research group evaluated the six standards chosen to the standardization of the EPP-AF ${ }^{\circledR}$, individually and combined, in Saccharomyces cerevisiae models, however no positive results were obtained with the standards when applied individually $(1,2,5,10,25,50,100$ and $200 \mu \mathrm{g} / \mathrm{ml})$ or combined $(100 \mu \mathrm{g} / \mathrm{ml}$ each one) similar to the observation made by Urushisaki et al. (2011) using an antiinfluenza model [29].

After the chemical and biological characterization of EPP-AF ${ }^{\circledR}$, the next step was to develop an interestingly pharmaceutical preparation, with a different and advantageous presentation to encourage patient compliance throughout the course of the treatment. For that, a polymeric system based on poloxamer 407 gel was proposed, due to the thermo reversible behavior and the stable arrangement of micelles that offered a stable and beautiful preparation. Also, the safety of this gel has previously been evaluated in in vitro and in vivo models [15].

Inflammation can be divided into acute, chronic and inflammation related to immunity. Any factor that induces the tissue damage could be described as the pathogenesis of inflammation. There are two types of factors that induce inflammation: inflammatory stimulating factor including physical stimuli, such as burns and surgery, or chemicals such as acids, alkalis, allergens; and biochemical (microorganisms, parasites, endotoxins, toxins). Another route of stimulating inflammation includes histamine, bradykinin, prostaglandins, platelet activating factor and pro-inflammatory stimulation factors (TNF- $\alpha$, IL-1, IL-6, cellular chemotaxis factor, etc.), among others [30].

The wound healing process occurs through a series of events coordinated and mediated by cytokines that require action in concert of many cell types. The first phase of the healing process is governed primarily by various inflammatory cells that accumulate within the wound. Platelets are among the first inflammatory mediators to arrive at the injury site, while neutrophils and macrophages arrive during the first two days after the injury occurred and typically precede the influx of fibroblasts, lymphocytes and endothelial cells. The well-orchestrated series of events within which these cell types interact includes the release of cytokines, growth factor and other bio- 
active molecules, such as free radicals [31] that when successful culminate in the functional restoration of tissue integrity.

In the present study, some samples of poloxamer gels were prepared with different concentrations of the propolis dry extract, since one of the objectives was to determine the best concentration of the propolis extract to promote wound healing and to kill or suppress the growth of microorganisms presented in burnt patients wounds.

The results demonstrated that the presence of propolis offered different results when compared to control (saline) and the poloxamer gel (without propolis), suggesting that samples 2 and 3 demonstrated better results. It is important to mention that the matrix formed is appropriate to the final objective, since larger quantities, than is required for the formation of reepithelization, can cause hypertrophic scars and keloids, due to the excessive deposition of extracellular matrix, mainly collagen, as well as other substances, such as glycoproteins, glycosaminoglycans and proteoglycans [32]. When antimicrobial activities of the gels were analyzed, samples 1 and 2 demonstrated absence of antibacterial activity against the bacterial strains tested. These samples contained lower concentrations of dry propolis extract (1.2 and $2.4 \%$, respectively). Sample 3 (3.6\% propolis), however, was effective against all microorganisms, suggesting this thermoreversible gel is the best option to achieve the objective of this work.

In the present model of study, epithelization concluded seven days after the injury. By this time, the structure of the subcutaneous tissue and collagen fibers, which provide support to the tissue, are completely reconstituted and a reorganization of the epithelial layer is observed, a process that culminates with the closing of the injury. In the treatments showed, histological sections were performed three days after the injury, showing the relevance of the results obtained.

The anti-inflammatory effect of propolis has been attributed to various mechanisms such as inhibiting the production of eicosanoids and nitric oxide, antioxidant action, modulation of calcium ion mobilization, angiogenesis and anti-leukocyte activity [33]. In the results presented here, it was observed that, when treated with the propolis gel, histological sections showed a decrease of leukocytes, the presence of new blood vessels (angiogenesis) and fibroblasts, corroborating to the mechanisms previous related.

The increased healing activity has been attributed to increased collagen formation and angiogenesis. Antioxidants have been shown to play a significant role in the healing and anti-inflammatory process [34]. This information has also been demonstrated in studies with asiaticoside, obtained from Centella asiatica, which also has an important healing action and demonstrated the increase of antioxidants in the new tissue formed after application of the active. This data suggested that the increase in antioxidant damaged areas can be an important factor in the healing process [31].

Numerous substances have been identified in propolis [35]. Its pharmacological properties, especially those related to antimicrobial, anti-inflammatory and wound healing properties, were mainly attributed to the presence of flavonoids and phenolic compounds [8]. It is scientifically proven that flavonoids reduce lipid peroxidation not only by preventing or delaying the onset of cellular necrosis, but also by increasing vascularization. It is believed that any drug that inhibits lipid peroxidation increases the feasibility of collagen fibers by increasing resistance and circulation, preventing cell damage and promotion of cell synthesis [36]. Furthermore, the flavonoids and terpenoids are also responsible for promoting the healing process of injuries, mainly due to their astringent and antimicrobial characteristics that appear to be responsible for the contraction of the lesion and the increased rate of epithelialization [36]. Also, flavonoids exhibit inhibitory activity of cyclooxygenase (COX) and lipooxigenase, reduction of prostaglandin E2 (PGE2) and expression of the inducible isoform of COX (COX-2).

\section{Conclusion}

In conclusion, the results of the chemical and biological characterization demonstrated the batch-to-batch reproducibility of the EPP-AF ${ }^{\circledR}$, considering the standards and microorganisms studied. Furthermore, this extract was effective against all microorganisms tested. The results suggest that a new thermoreversible pharmaceutical form containing propolis as active ingredient can offer an alternative therapeutics to treat skin injuries, since this preparation was effective against all microorganisms tested and demonstrated favorable result on the wound healing model used.

\section{Acknowledgments}

The authors would like to thank Lucila Hirooka and Laurelúcia Lunardi, for histological assistance, Alexandre H. Oliveira, Edna A. Barizon, Ana Rita de Melo Costa-Machado, Flávia Silva Marquiafável, Bruno A. Rocha, Marina R. Rodrigues and Nathália Ursoli Ferreira for technical assistance, and finally, Neil Brown for english revision. 


\section{Competing Interests}

The authors have declared that no competing interest exists.

\section{References}

1. Nasser S, Mabrouk A, Maher A. Colonization of burn wounds in Shams University Burn Unit. Burns. 2003;29:229-233.

2. Gerding R L, Emerman CL, Effron D, Lukens T, Imbembo AL, Fratianne RB. Outpatient management of partial-thickness burns: Biobrane ${ }^{\circledR}$ versus $1 \%$ silver sulfadiazine. Ann Emerg Med. 1990;19:121-124.

3. Nalbandian RM, Henry RL, Balko KW, Adams DV, Neuman NR. Pluronic F-127 gel preparation as an artificial skin in the treatment of third-degree burns in pigs. J Biomed Mater Res. 1987; 21:1135-1148.

4. Cabana A, Ait-Kadi A, Juhasz J. Study of the gelation process of polyethylene oxide-polypropylene oxide- polyethylene oxide copolymer (poloxamer $407^{\circledR}$ ) aqueous solution. J Colloid Interf Sci. 1997;190:307-312.

5. Simões LMC, Gregório LE, da Silva Filho AA, de Souza ML, Azzolini AECS, Bastos JK, Lucisano-Valim YM. Effect of Brazilian green propolis on the production of reactive oxygen species by stimulated neutrophils. J Ethnopharmacol. 2004;94:59-65.

6. Park YK, Ikegaki M. Preparation of water and ethanolic extracts of propolis and evaluation of the preparations. Biosci Biotechnol Biochem. 1998;62:2230-2232.

7. Burdock GA. Review of the biological properties and toxicity of bee propolis. Food Chem Toxicol. 1998; 36:347-363.

8. Borrelli F, Maffia P, Pinto L, Ianaro A, Russo A, Capasso F et al. Phytochemical compounds involved in the anti-inflammatory effect of propolis extract. Fitoterapia. 2002; 73:S53-S63.

9. Diaz JCQ, Rodrigues OA, Velázquez MD, Miliá NML. Empleo de la tintura de propóleo en la cura de heridas sépticas faciales. Rev Cuba Estomatol. 1997; 34:347-351.

10. Koo H, Gomes BPFA, Rosalen PL, Ambrosano GMB, Park YK, Cury JA. In vitro antimicrobial activity of propolis and Arnica montana against oral pathogens. Arch Oral Biol. 2000; 45:141-148.

11. Reis CMF, Carvalho JCT, Caputo LRG, Patricio KCM, Barbosa MVJ, Chieff AL, et al. Atividade antiinflamatória, anti-úlcera gástrica e toxicidade subcrônica do extrato etanólico de própolis. Rev Bras Farmacogn. 2000;9-10:43-52.

12. Barros MP, Sousa JPB, Bastos JK, Andrade SF. Effect of Brazilian green propolis on experimental gastric ulcers in rats. J Ethnopharmacol 2007;110: 567-571.

13. Rezende GPSR, Pimenta FC, Costa LRRS. Antimicrobial activity of two Brazilian commercial propolis extracts. Braz J Oral Sci 2006;5:967-970

14. De Castro PA, Savoldi M, Bonatto D, Barros MH, Goldman MHS, Berretta AA, et al. Molecular characterization of propolis-induced cell death in Saccharomyces cerevisiae. Eukaryotic Cell. 2011;10:398-411.

15. Senedese JM, Rodrigues AR, Furtado MA, Faustino VD, Berretta AA, Marchetti JM, et al. Assessment of the mutagenic activity of extracts of Brazilian propolis in topical pharmaceutical formulations on mammalian cells in vitro and in vivo. Evid Based Complement Alternat Med 2008;doi:10.1093/ecam/nen049.

16. Tavares DC, Lira WM, Santini CB, Takahashi CS, Bastos JK. Effects of propolis crude hydroalcoholic extract on chromosomal aberrations induced by doxorubicin in rats. Planta Med. 2007;73:1531-1536.

17. Czaja W, Krystynowicz A, Bielecki S, Brown Jr RM. Microbial cellulose - the natural power to heal wounds. Biomater. 2006; 27:145-151.

18. Sousa JPB, Bueno PCP, Gregório LE, Silva Filho AA, Furtado NAJC, Sousa ML, et al. A reliable quantitative method for the analysis of phenolic compounds in Brazilian propolis by reverse phase high performance liquid chromatography. J Sep Sci. 2007;30:2656-2665.

19. Schmolka IV. Artificial skin I. preparation and properties of Pluronic f.-127 gels of treatment of burns. J Biomed Mat Res. 1972; 6:571-82.

20. National Committee for Clinical Laboratory Standards. Methods for dilution antimicrobial susceptibility tests for bacteria that grow aerobically; approved standard, 6th ed. NCCLS document M7-A6, 2003.

21. Hu RH, Yu YM, Costa DBS, Young VR, Ryan CM, Burke JF, et al. A rabbit model for metabolic studies after burn injury. J Surg Res. 1998;75:153-158.

22. Magro-Filho O, de Carvalho AC. Application of propolis to dental sockets and skin wounds. I Nihom Univ Sch Dent. 1990;32:4-13.

23. Junqueira LC, Carneiro J. Histologia Básica. Rio de Janeiro, Brasil: Guanabara Koogan; 2004.

24. Sforcin JM, Bankova V. Propolis: Is there a potential for the development of new drug? J Ethnopharmacol. 2011;133: 253-260.

25. Almeida, IF, Costa, PC, Bahia, MF. Evaluation of Functional Stability and Batch-to-Batch Reproducibility of a Castanea sativa Leaf Extract with Antioxidant Activity. AAPS PharmSciTech. 2010;11(1):120-125.

26. Erkmen O, Özcan MM. Antimicrobial effects of Turkish propolis, pollen, and laurel on spoilage and pathogenic food-related microorganisms. J Med Food. 2008;11:587-592.

27. Menna-Barreto RFS, Salomão K, Dantas AP, Santa-Rita RM, Soares MJ, Barbosa HS, De Castro SL. Review - Different cell death pathways induced by drugs in Trypanosoma cruzi: An ultrastructural study. Micron. 2009;40(2):157-168.

28. Takaisi NB and Schilcher H. Electron microscopy and microcalorimetric investigations of the possible mechanism of the antibacterial action of a defined propole provenance. Planta Med. 1994;60: 222-227.

29. Urushisaki, T, Takemura, T, Tazawa, S, Fukuoka, M, Hosokawa-Muto, J, Araki, W, Kuwata, K. Caffeoylquinic Acids Are Major Constituents with Potent Anti-Influenza Effects in Brazilian Green Propolis Water Extract. ECAM. 2011. doi:10.1155/2011/254914

30. Akarasereenont P, Mitchell JA, Bakhle C, Thiemermann C, Vane JR. Comparison of the induction of cyclooxigenase and nitric oxide synthase by endotoxin in endothelial cells and macrophages. Eur J Pharmacol. 1995; 273:121-128.

31. Shukla A, Rasik AM, Patnaik K. Depletion of reduced glutathione, ascorbic acid, vitamin E and antioxidant defence enzymes in a healing cutaneous wound. Free Radical Res. 1997;26: 93-101.

32. Amadeus TP, Braune AS, Porto LC, Desmoulière A, Costa AMA. Fribrillin-1 an elastin are differentially expressed in hypertrophic scars and keloids. Wound Repair Regen. 2004; 12:169-174.

33. Naito $Y$, Yasumuro M, Kondou K, Ohara N. Antiinflammatory effect of topically applied propolis extract in carrageenan-induced rat hind paw edema. Phytoth Res. 2007;21:452-456.

34. Volpert R, Elstner EF. Interactions of different extracts of propolis with leukocytes and leukocytic enzymes. Arzn-Forsch/Drug Res. 1996;46:47-51.

35. Bankova V, Castro SL, Marcucci MC. Propolis: recent advances in chemistry and plant origin. Apidol. 2000; 31:3-15.

36. Nayak S, Nalaboth P, Sandiford S, Bhogadi V, Adogwa A. Evaluation of wound healing activity of Allamanda cathartica. $L$. and Laurus nobilis. L. extracts on rats. BMC Complement Altern Med. 2006:6:12. 